\title{
Strategi Manajemen Pembelajaran Pada Masa Covid-19 di SMK Ma'arif 9 Kebumen
}

Agus Nur Soleh M.Pd.

Dosen IAINU Kebumen

:agusnursoleh06@gmail.com
Arum Murniati, Iqbal Fawaidul M, Laelatul Istiqomah, M.Rifqi Alhabib, Rifki Najmuddin, Fatihatur Rohmah, Risko Krisma Prianto dan Umi Sakhiyyah. Mahasiswa: IAINU Kebumen

\begin{abstract}
Abstrak
Penulisan karya ilmiah ini merupakan hasil penelitian kolaboratif tentang Manajemen Kurikulum dan Pembelajaran di Masa Covid-19 di SMK Ma'arif 9 Kebumen. Penelitian ini bertujuan untuk mengetahui manajemen kurikulum dan pembelajaran pada masa covid-19. Rumusan masalah dalam artikel ini adalah (1) Bagaimana manajemen kurikulum dan pembelajaran pada masa covid-19 di SMK Ma'arif 9 Kebumen? (2) Bagaimana hasil analisa swot terhadap manajemen kurikulum dan manjemen pembelajaran di SMK Ma'arif 9 Kebumen? Penelitian ini menggunakan metode penelitian kualitatif dengan teknik wawancara, observasi, dan dokumentasi serta analisa SWOT yang dilaksanakan pada tanggal 20 - 24 Juli 2020 di SMK Ma'arif 9 Kebumen. Informan dari penelitian ini diantaranya kepala sekolah, waka kurikulum, dan kepala jurusan. Hasil dari penelitian ini adalah SMK Ma'arif 9 Kebumen tetap menggunakan kurikulum yang sama seperti sebelum terjadi pandemi yaitu kurikulum 2013. Meskipun ada beberapa perubahan di dalam proses pembelajaran, dimana proses pembelajaran yang tadinya menggunakan metode tatap muka diubah dengan beberapa metode untuk menyesuaikan protokol kesehatan diantaranya metode daring, dan lain sebagainya.
\end{abstract}

\section{Kata Kunci :Manajemen, Kurikulum, Pembelajaran, Covid-19.}




\begin{abstract}
The writing this scientific paper is the result of collaborative research on Curriculum Management and Learning in the Covid-19 Period at SMK Ma'arif 9 Kebumen. This study aims to determine curriculum management and learning in the covid-19 period. The formulation of the problem in this article is (1) How was curriculum management and learning in the covid-19 years at SMK Ma'arif 9 Kebumen? (2) What are the results of the SWOT analysis of curriculum management and learning management at SMK Ma'arif 9 Kebumen? This study uses qualitative research methods with interview, observation, and documentation as well as SWOT analysis techniques conducted on July 20-24, 2020 at SMK Ma'arif 9 Kebumen. Informants from this study include the principal, curriculum waka, and the head of the department. The results of this study are the SMK Ma'arif 9 Kebumen continue to use the same curriculum as before the pandemic, namely the 2013 curriculum. Although there are some changes in the learning process, where the learning process that used the face-to-face method was changed by several methods to adjust the health protocol including online methods, and so on.
\end{abstract}

Keywords: Management, Curriculum, Learning, Covid-19

\title{
A. Pendahuluan
}

SMK Maarif 9 Kebumen merupakan sekolah menengah atas kejuruan yang didirikan oleh Lembaga pendidikan Ma'arif NU Kebumen sejak 2003. Sekolah tersebut memiliki 3 jurusan diantaranya jurusan teknik kendaraan ringan, akutansi, dan rekayasa perangkat lunak. Dari awal mula didirikan tahun 2003, sekolah ini sudah menjelma menjadi sekolah favorit di Kebumen. Hal itu dapat di lihat dari jumlah siswa keseluruhan yang sudah mencapai 1200 siswa. Tentunya hal itu tidak terlepas dari kualitas SMK Ma'arif 9 Kebumen yang dipandang baik oleh masyarakat.

Salah satu unsur keberhasilan peningkatan kualitas adalah dengan menerapkan strategi pembelajaran yang tepat. Strategi pembelajaran merupakan salah satu unsur dari proses pembelajaran. Strategi pada hakikatnya adalah prosedur yang sistematis dalam pelaksanaan pengajaran yang merupakan pertanggungjawaban dari pemahaman pendidik atas tujuan dan organisasi pengajaran serta isi pelajaran. Strategi digunakan oleh guru dan siswa untuk mengkreasikan proses pembelajaran yang dilaksanakan di dalam kelas sehingga tujuan pembelajaran dapat dicapai. 
Manajemen pembelajaran itu sendiri merupakan proses mengelola yang meliputi kegiatan perencanaan, pengorganisasian, pengendalian, dan pengevaluasian kegiatan yang berkaitan dengan proses membelajarkan si pembelajar dengan mengikutsertakan berbagai faktor di dalamnya guna mencapai tujuan. ${ }^{1}$

Adanya perkembangan ilmu pengetahuan dan teknologi serta perubahan paradigma pendidikan di era revolusi industry 5.0 yang mengembangkan digitalisasi di setiap lininya tak terkecuali pendidikan menuntut guru lebih inovatif dalam merancang pembelajaran, artinya guru harus melakukan reformasi kelas dalam menyusun maupun melaksanakan pembelajaran.

Beberapa riset sebelumnya, misalnya riset yang dilakukan oleh bapak Agus Salim Chamidi, dkk di SMK Ma'arif 1 Kebumen yang menggunakan analisis SWOT manajemen pendidikan yang berfokuskan pada 4 bidang yaitu, manajemen kurikulum dan pembelajaran, manajemen pendidik dan tenaga kependidikan, manajemen peserta didik, dan manajemen hubungan industri dan masyarakat serta dilakukan sebelum masa pandemic covid- $19^{2}$.

Riset ini hanya berfokus pada manajemen kurikulum dan pembelajarannya saja, serta dilakukan pada masa pandemi covid-19. Hasilnya bila kurikulum dan pembelajaran yang dipakai di SMK Ma'arif 9 Kebumen sebelum pandemi menggunakan K13 atau pembelajaran normal dengan penilaian menggunakan tugas terstruktur dan nilai semester, maka di riset ini hasilnya ada perubahan dalam penerapan kurikulum di SMK Ma'arif 9 Kebumen, yaitu menggunakan kurikulum darurat covid-19 serta menggunakan metode pembelajaran jarak jauh.

Sejak merebaknya pandemi yang disebabkan oleh virus covid-19 di Indonesia pada bulan maret lalu, banyak cara yang dilakukan oleh pemerintah untuk mengatur sistem pembelajaran. Salah satunya adalah dengan mengeluarkan Surat Edaran Nomor 4 Tahun 2020 tentang Pelaksanaan Kebijakan Pendidikan dalam Masa Darurat Penyebaran Covid-19, yang menjelaskan bahwa proses

\footnotetext{
${ }^{1}$ Syaiful Sagala. Konsep dan Makna Pembelajaran. Bandung:Alfabeta. 2009. hlm.43

${ }^{2}$ Agus Salim Chamidi,dkk. Analisa SWOT Manajemen Pendidikan di SMK Ma'arif 1 Kebumen. Ejournal,Cakrawala: Studi Manajemen Pendidikan Islam dan Studi Sosial. 2019. Vol3.No2.
} 
pembelajaran dilaksanakan di rumah melalui pembelajaran virtual/daring (dalam jaringan) untuk memberikan pengalaman belajar yang bermakna pada peserta didik. $^{3} \quad$ Pembelajaran daring merupakan proses pembelajaran dengan menggunakan teknologi digital seperti HP, Laptop, dan lain sebagainya.

\section{B. Metode}

Penelitian ini bersifat kualitatif. Permasalahan akan dicari jawabannya melalui teknik wawancara, observasi, dan dokumentasi. Informan riset adalah kepala sekolah SMK Maarif 9 Kebumen, wakil kepala bidang kurikulum, dan kepala jurusan. Data hasil riset akan dianalisis menggunakan model analisa SWOT dengan pendekatan kualitatif yaitu alat analisis yang ditujukan untuk menggambarkan situasi yang sedang dihadapi atau mungkin dihadapi oleh organisasi.

Analisis SWOT terdiri dari 4 komponen dasar yaitu, (a) strengths (S) yaitu kekuatan suatu organisasi ; (b) weaknesses (W) yaitu kelemahan dari suatu organisasi ; (c) opportunities (O) yaitu peluang yang berasal dari luar organisasi ; (d) threats (T) yaitu ancaman bagi organisasi yang berasal dari luar.

Menurut Freddy Rangkuti, analisa SWOT diartikan sebagai analisa yang didasarkan pada logika yang dapat memaksimalkan kekuatan (strengths) dan peluang (opportunities), namun secara bersamaan meminimalkan kelemahan (weaknesses) dan ancaman (threats). ${ }^{4}$

Riset dilakukan pada tanggal 20-25 Juli 2020 melalui kerja kelompok mahasiswa dengan bimbingan dosen dalam kegiatan kurikuler Program Latihan Profesi (PLP)/Magang I Program Studi S1 Manajemen Pendidikan Islam IAINU Kebumen yang bertempatkan di SMK Ma'arif 9 Kebumen yang beralamat di Jalan Raya Klirong, Desa Klegenwonosari, Kec. Klirong 54381.

\section{Landasan Teori}

\footnotetext{
${ }^{3}$ https:// covid19.go.id/p/regulasi/surat-edaran-nomor-4-tahun-2020 diakses pada 23 Juli 2020 jam 22:45 WIB

${ }^{4}$ Freddy Rangkuti. Analisa SWOT Teknik Membedah Kasus Bisnis. Jakarta:Gramedia Pustaka Utama. 2013. hal.19
} 


\section{Pengertian Manajemen}

Manajemen adalah ilmu dan seni mengatur proses pemanfaatan sumber daya manusia dan sumber-sumber lainnya secara efektif dan efisien untuk mencapai suatu tujuan tertentu, (Drs. H. Malayu S.P. Hasibuan 1985) ${ }^{5}$. Sedangkan menurut Mary Parker Follet yg dikutip oleh Handoko (2000:8) manajemen merupakan seni dalam menyelesaikan pekerjaan melalui orang lain. Definisi ini mengandung arti bahwa para manajer mencapai tujuan-tujuan organisasi melalui pengaturan orang-orang lain utk melaksanakan berbagai tugas yg mungkin diperlukan ${ }^{6}$. Dengan demikian dapat disimpulkan bahwa manajemen adalah seni mengatur pemanfaatan sumber daya manusia dan sumber lainnya secara efektif dan efisien untuk mencapai tujuan-tujuan organisasi melalui orang lain untuk melaksanakan tugas yang mungkin diperlukan.

\section{Pengertian Kurikulum}

Menurut Dr. H. Nana Sudjana tahun (2005), kurikulum merupakan niat \& harapan yang dituangkan kedalam bentuk rencana maupun program pendidikan yang dilaksanakan oleh para pendidik di sekolah. Kurikulum sebagai niat \& rencana, sedangkan pelaksaannya adalah proses belajar mengajar. Yang terlibat didalam proses tersebut yaitu pendidik dan peserta didik.

Sedangkan menurut Prof.Dr. Henry Guntur Tarigan kurikulum ialah suatu formulasi pedagogis yang termasuk paling utama dan terpenting dalam konteks proses belajar mengajar. ${ }^{7}$

Dari beberapa pembahasan diatas dapat disimpulkan bahwa kurikulum merupakan niat \& harapan yang dituangkan kedalam bentuk rencana maupun program pendidikan yang dilaksanakan oleh para pendidik di sekolah dan merupakan suatu formulasi pedagogis yang termasuk paling utama dan terpenting dalam konteks proses belajar mengajar.

\footnotetext{
${ }^{5}$ Drs. H. Malayu S.P. Hasibuan, Dasar-Dasar Perbankan, Jakarta: Bumi Aksara, 2004, hal. 54 ${ }^{6}$ Rahmat, DefinisiManajemen, disalindari website: http://blog.re.or.id/definisi-manajemen.htm ${ }^{7}$ http://www.definisi-pengertian.com/2016/01/pengertian-kurikulum-definisi-menurut-ahli.html/ diakses pada 24 Juli 2020 jam 09:48
} 
3. Pengertian Pembelajaran

Belajar dapat didefinisikan sebagai suatu proses dimana suatu oganisma berubah perilakunya sebagai akibat dari pengalaman. Belajar pada hakekatnya adalah suatu aktivitas yang mengharapkan perubahan tingkah laku pada diri individu yang sedang belajar. Dari konsep belajar muncul istilah pembelajaran. Yang dapat diartikan pembelajaran sebagai upaya membelajarkan siswa. ${ }^{8}$ Pembelajaran sebagai suatu rangkaian kegiatan (kondisi, peristiwa, kejadian, dsb) yang sengaja dibuat untuk mempengaruhi pembelajar, sehingga proses belajarnya dapat berlangsung mudah. Pembelajaran bukan hanya terbatas pada kegiatan yang dilakukan guru, seperti halnya dengan konsep mengajar. Pembelajaran mencakup semua kegiatan yang mungkin mempunyai pengaruh langsung pada proses belejar manusia. Pembelajaran mencakup pula kejadian-kejadian yang diturunkan oleh bahanbahan cetak, gambar, program radio, televisi, film, slide maupun kombinasi dari bahan-bahan itu. Bahkan saat ini berkembang pembelajaran dengan pemanfaatan berbagai program komputer untuk pembelajaran atau dikenal dengan e-learning. ${ }^{9}$

\section{Hasil dan Pembahasan}

1. Manajemen Kurikulum dan Pembelajaran

Manajemen kurikulum merupakan salah satu aspek yang berpengaruh terhadap keberhasilan pembelajaran dalam pendidikan. Di samping itu, kurikulum merupakan suatu sistem program pembelajaran untuk mencapai tujuan institusional pada lembaga pendidikan, sehingga kurikulum memegang peranan penting dalam mewujudkan sekolah yang bermutu atau berkualitas ${ }^{10}$.

Penyusunan kurikulum di SMK Ma'arif 9 Kebumen dilakukan oleh tim penyusun kurikulum yang terdiri dari Kepala Sekolah, Wakil Kepala Sekolah Bidang Kurikulum beserta stafnya, kepala jurusan dan ketua kelompok kerja

\footnotetext{
${ }^{8}$ Made Pidarta, Manajemen Pendidikan Indonesia (Jakarta : Rineka Cipta, 2004) h.74

${ }^{9}$ Ibid., h.78

${ }^{10}$ https://sumberbelajarangga.wordpress.com/2012/12/10/makalah-manajemen-kurikulum-danpembelajaran/ diakses pada 23 juli 2020 jam 06.38 WIB
} 
tiap mata pelajaran. Tim ini nantinya akan menghasilkan buku kurikulum. Buku kurikulum ini akan menjadi dasar penyusunan silabus, program tahunan (prota), program semester (promes) dan Rencana Pelaksanaan Pembelajaran (RPP) yang di dalamnya terdapat Kompetensi Inti (KI), Kompetensi Dasar (KD), indikator hasil belajar, dan Penilaian Berbasis Kelas (PBK) ${ }^{11}$.

Untuk mendukung kemudahan dalam penilaian terhadap siswa, Guru memberikan tugas kepada siswa. Selain itu terdapat juga ujian penilaian tengah semester dan penilaian semester. Setelah proses pembelajaran selesai dilaksanakan, guru melakukan evaluasi dari pemahaman yang diperoleh oleh siswa. Selain penilaian pembelajaran, guru juga melakukan evaluasi dari sikap siswa yang dapat diketahui dari lembar penilaian sikap yang di miliki oleh tiap guru mata pelajaran.

Akan tetapi sejak adanya pandemi covid-19 yang telah terjadi di Indonesia, banyak sekolah yang merubah strategi pembelajaran di sekolah masing-masing sebagai bentuk kepatuhan terhadap pemerintah yang menganjurkan untuk mengurangi kegiatan yang bersifat masal seperti aturan yang dikeluarkan oleh Gubernur Ganjar Pranowo guna menghadapi Jawa Tengah tanggap darurat covid-19.

Dengan adanya aturan tersebut, SMK Ma'arif 9 Kebumen merubah strategi pembelajaran mereka sesuai dengan anjuran yang berikan pemerintah yaitu pembelajaran jarak jauh (daring). Metode pembelajaran jarak jauh di SMK Ma'arif 9 Kebumen menggunakan aplikasi google classroom dan whatsapp. Hal itu bertujuan untuk mengurangi beban tugas terhadap siswa dengan adanya larangan pembelajaran tatap muka dan untuk membatasi anak agar tidak terlalu banyak bermain.

Metode pembelajaran jarak jauh tentunya mempunyai banyak sekali kekurangan dibandingkan dengan pembelajaran tatap muka, disamping harus adanya perangkat pendukung seperti handphone, laptop,dll pembelajaran jarak jauh juga harus didukung dengan kuota data yang mumpuni agar dapat berjalan lancar. Akan tetapi banyak kasus yang terjadi dilapangan seperti adanya

\footnotetext{
${ }^{11}$ Agus Salim Chamidi,dkk. Op. cit. hlm 168
} 


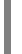

sebagian orang tua yang masih GAPTEK terhadap teknologi, dan permasalahan lain seperti kehabisan kuota data.

Menanggapi hal tersebut, sekolah memberikan keringanan terhadap siswa yang memiliki masalah dengan adanya pemebelajaran jarak jauh yaitu dengan memperbolehkan belajar bersama teman terdekat sehingga pada waktu adanya jam pelajaran, siswa tersebut tetap dapat mengikuti pembelajaran tanpa ada rasa kecewa.

Disamping adanya pembelajaran jarak jauh atau daring yang diterapkan di SMK Ma'arif 9 Kebumen di masa pandemi covid-19, sekolah juga menyelenggarakan pembelajaran tatap muka seperti sebelum adanya pandemi covid-19 dengan durasi waktu seminggu 2 kali, terjadwal sebagai berikut :

- Hari Senin dan Kamis : kelas 10

- Hari Selasa dan Jum' at : kelas 11

- Hari Rabu dan Sabtu : : kelas 12

Akan tetapi ada perbedaan yang cukup signifikan seperti pengurangan jam pembelajaran pada beberapa mata pelajaran. Sebagai contoh mata pelajaran produktif seperti bahasa indonesia dan matematika dari yang awalnya 6 jam menjadi 4 jam. Dan pelajaran non produktif dari yang awalnya 3 jam menjadi 2 jam. Untuk ekstrakurikuler di SMK Ma'arif 9 Kebumen sebagian besar tidak dilaksanakan kecuali ekstrakulikuler bela diri, karena dianggap dapat menjaga kebugaran jasmani para siswa.

Dengan adanya hal tersebut tentu menjadi tekanan bagi guru dan juga siswa. Guru harus mampu memonitoring siswa didiknya melalui media komunikasi sehingga perlu adanya penyesuaian terhadap media komunikasi agar dapat berjalan maksimal. Tidak hanya mampu menjalankan aplikasi google classroom, whatsapp, dll serta sebagai konsumen, siswa juga diajarkan bagaimana membuat grup di google classroom dan whatsapp, dan diharapkan mampu berinovasi lebih untuk menunjang nilai siswa di akhir semester.

2. Analisa SWOT Manajemen Kurikulum dan Pembelajaran

a. Analisa SWOT berdasarkan standar isi 
Kekuatan (strengths)

Kelemahan

(weaknesses)

Peluang

(opportunities)
- Kurikulum yang digunakan merupakan perpaduan antara kurikulum kementrian agama dan kurikulum kementrian pendidikan dan kebudayaan yang diberikan secara profesional dan berkesinambungan.

- Kalender pendidikan sudah mengacu kepada kalender Pendidikan Nasional.

- Kolaborasi pendidikan umum dengan pendidikan kepesantrenan.

- Masih minimnya inovasi pengembangan kurikulum.

- Apresiasi masyarakat terhadap SMK Ma'arif 9 Kebumen semakin meningkat

- Adanya ruang gerak yang terbuka bagi lembaga pendidikan untuk mengembangkan diri secara maksimal.

\section{Ancaman (threats) \\ - Adanya sekolah sejenis di daerah tersebut yang memiliki kurikulum lebih baik.}

Berdasarkana analisis SWOT diatas maka rencana strategi yang perlu dibuat diantaranya :

1. Strategi SO, yaitu menggunakan kekuatan dan memanfaatkan peluang.

Berdasarkan beberapa analisa SWOT diatas, terdapat kekuatan serta peluang yang merupakan sisi positif dari SMK Ma'arif 9 Kebumen sehingga dapat meningkatkan kualitas dari sekolah tersebut. Dalam strategi SO dapat memanfaatkan peluang dengan menggunakan kekuatan yang ada. Misalnya kurikulum yang digunakan merupakan perpaduan antara kurikulum kementrian agama dan kurikulum kementrian pendidikan dan kebudayaan yang diberikan secara profesional dan berkesinambungan serta kolaborasi pendidikan umum 
Jurnal Cakrawala: Studi Manajemen Pendidikan Islam dan Studi

Sosial P-ISSN: 2580-9385, E-ISSN: 2581-0197

http:/ / ejournal.iainu-kebumen.ac.id/index.php/ cka/ index

dengan pendidikan kepesantrenan menjadi kekuatan bagi SMK Ma'arif 9

Kebumen sehingga dapat meningkatkan apresiasi dari masyarakat terhadap sekolah.

2. Strategi WO, yaitu memperbaiki kelemahan dan memanfaatan peluang.

Strategi yang kedua yaitu dengan memperbaiki kelemahan dan memanfaatkan peluang. Untuk itu perlu meningkatkan inovasi pengembangan kurikulum dengan sebaik mungkin, sejalan dengan kebebasan ruang gerak lembaga pendidikan untuk mengembangkan diri secara maksimal demi tercapainya perbaikan mutu pendidikan di SMK Ma'arif 9 Kebumen.

3. Strategi ST, yaitu menggunakan kekuatan dan menghindari ancaman.

Selain strategi memperbaiki kelemahan dan memanfaatkan peluang, ada juga strategi meggunakan kekuatan dan menghindari ancaman. Dengan adanya kolaborasi pendidikan umum dengan pendidikan kepesantrenan dapat menarik minat siswa dan orang tua dalam memilih sekolah yang berbasis islami sehingga dapat meminimalisir atau menghindari persaingan dengan sekolah lain yang sejenis .

4. Strategi WT, yaitu mengatasi kelemahan dan menghindari ancaman.

Dari deskripsi tabel tersebut dapat diketahui kelemahan dan ancaman yang di hadapi oleh SMK Ma'arif 9 Kebumen dalam bidang kurikulum. Kelemahan tersebut adalah masih minimnya inovasi dalam pengembangan kurikulum. Cara mengatasinya yaitu harus di kaji ulang agar sesuai dengan kebutuhan masa kini. Selain kelemahan ada juga ancamannya yaitu banyak sekolah lain sejenis yang memiliki kurikulum lebih baik. Untuk menghadapi ancaman tersebut, perlu adanya pengkajian ulang terhadap penyusunan kurikulum sehingga menarik minat siswa.

b. Analisa SWOT berdasarkan standar proses 
http.//ejo

Kekuatan (strengths)

\section{Kelemahan \\ (weaknesses)}

Peluang

(opportunities)

Ancaman (threats)
- Pembuatan RPP tepat waktu

- Perangkat pembelajaran masing-masing bidang studi sudah lengkap

- Mayoritas guru sudah memiliki sertifikat pendidik.

- Sekolah belum sepenuhnya siap dengan proses pembelajaran daring

- Pemerintah membebaskan lembaga pendidikan menggunakan sistem daring yang akan digunakan

- Adanya keterbatasan orang tua dalam menyediakan fasilitas belajar bagi anakanaknya

Berdasarkana analisis SWOT diatas maka rencana strategi yang perlu dibuat diantaranya :

1. Strategi SO, yaitu menggunakan kekuatan dan memanfaatkan peluang.

Dengan adanya perangkat pembelajaran masing-masing bidang studi yang sudah lengkap, sekolah atau lembaga bebas menentukan sistem pembelajaran daring yang akan digunakan sehingga meningkatkan kreativitas guru.

2. Strategi WO, yaitu memperbaiki kelemahan dan memanfaatan peluang Sekolah memperisiapkan diri dari segi pendidik dan fasilitas dengan memanfaatkan kebebasanan yang diberikan oleh pemerintah dalam menggunakan sistem daring yang akan digunakan.

3. Strategi ST, yaitu memanfaatkan kekuatan untuk menghindari ancaman

Strategi dengan memanfaatkan kekuatan untuk menghindari ancaman yaitu dengan sekolah menyediakan fasilitas bagi siswa yang memiliki keterbatasan fasilitas untuk pembelajaran daring.

4. Strategi WT, yaitu memperkecil kelemahan dan menghindari ancaman. 
Strategi yang terakhir yaitu memperkecil kelemahan dan menghindari ancaman. Berdasarkan analisa SWOT tersebut strategi yang digunakan dalah sekolah mempersiapakan diri dari segi pendidik dan fasilitas guna membantu siswa yang memiliki keterbatasaan dalam pembelajaran.

\section{Kesimpulan}

Hasil dari penelitian ini adalah SMK Ma'arif 9 kebumen tetap menggunakan kurikulum yang sama seperti sebelum terjadi pandemi yaitu kurikulum 2013. Meskipun ada beberapa perubahan di dalam proses pembelajaran, dimana proses pembelajaran yang tadinya menggunakan metode tatap muka diubah dengan beberapa metode untuk menyesuaikan protokol kesehatan diantaranya metode daring, dan lain sebagainya.

Dalam analisa SWOT manajemen kurikulum dan pembelajaran pada masa covid-19, sekolah belum sepenuhnya siap dalam melakukan proses pembelajaran daring. Hal tersebut dikarenakan pandemi yang datang secara mendadak. Namun pihak sekolah tetap berusaha untuk menyesuaikan dengan keadaan dan mempersiapkan diri baik dari segi pendidik maupun fasilitas dengan memanfaatkan kebebasanan yang diberikan oleh pemerintah dalam menggunakan sistem daring yang akan digunakan.

\section{Daftar Pustaka}

- Chamidi, Agus Salim. dkk. 2019. Analisa SWOT Manajemen Pendidikan di SMK Ma'arif 1 Kebumen. Ejournal,Cakrawala,volume 2 no 1 tahun 2018.

- Hasibuan, Malayu S.P. 2004.Dasar-Dasar Perbankan.Jakarta: Bumi Aksara.

- https://covid19.go.id/p/regulasi/surat-edaran-nomor-4-tahun-2020 diakses pada 23 Juli 2020 jam 22:45 WIB.

- https://sumberbelajarangga.wordpress.com/2012/12/10/makalahmanajemen-kurikulum-dan-pembelajaran/ diakses pada 23 juli 2020 jam 06.38 WIB. 
\begin{tabular}{l|l|l} 
Jurnal Cakrawala: Studi Manajemen Pendidikan Islam dan Studi & Vol.4 No.2 Th 2020
\end{tabular} Sosial P-ISSN: 2580-9385, E-ISSN: 2581-0197 http:/ / ejournal.iainu-kebumen.ac.id/index.php/ cka/ index

- http://www.definisi-pengertian.com/2016/01/pengertian-kurikulumdefinisi-menurut-ahli.html/ diakses pada 24 Juli 2020 jam 09:48.

- Pidarta, Made. 2004. Manajemen Pendidikan Indonesia.Jakarta: Rineka Cipta.

- Rahmat, Definisi Manajemen, disalin dari website: http://blog.re.or.id/definisi-manajemen.htm.

- Rangkuti, Freddy. 2013.Analisa SWOT Teknik Membedah Kasus Bisnis. Jakarta: Gramedia Pustaka Utama.

- Sagala, Syaiful. 2009. Konsep dan Makna Pembelajaran. Bandung: Alfabeta. 